\title{
ALGORITMA WELCH-POWELL UNTUK PEWARNAAN GRAF PADA PENJADWALAN PERKULIAHAN
}

\author{
Yulianti Rusdiana $^{1}$, Alfi Maulani ${ }^{2}$ \\ Universitas Pamulang 1,2 \\ yulianti.rusdiana@gmail.com ${ }^{1}$
}

Submit, 31-10-2019 Accepted, 27-12-2019 Publish, 28-12-2019

\begin{abstract}
The problem that often faced is the lecture timetable and course distribution are still manually and have not fully paid attention to the field of science that matches the interests of the lecturer. To overcome these problems, the authors use Welch-Powell's algorithm to arrange lecture arrangement schedules with expectations that the scheduling will be faster and optimal and more satisfying to various parties. The results of applying Welch-Powell's Algorithm to the willingness of lecturers to teach available courses provide four colors. The results are used to map lecturers and subjects that are supported by class availability to ensure that lecturers with the same course choices must be placed in different classes. In meeting class needs, one lecturer can handle several subjects, and several lecturers can teach one subject. The results of applying the Welch-Powell Algorithm to the suitability of teaching time give 29 colours. These results are used to map lecture time to ensure that lecturers with the same choice of time should be provided in different classes.
\end{abstract}

Keywords: Vertex, Colouring, Welch-Powell's algorithm

\begin{abstract}
Abstrak: Penjadwalan adalah kegiatan administratif utama di sebagian besar universitas. Permasalahan yang sering dihadapi adalah pengaturan waktu perkuliahan dan pembagian mata kuliah masih dilakukan secara manual dan belum sepenuhnya memperhatikan bidang ilmu yang diminati dosen dan kesediaan dosen. Untuk mengatasi permasalahan tersebut, penulis menggunakan algoritma WelchPowell untuk menyusun jadwal pengaturan perkuliahan dengan harapan penjadwalan yang dilakukan nantinya akan lebih cepat dan optimal serta lebih memuaskan berbagai pihak. Hasil penerapan Algoritma Welch-Powell terhadap kesediaan dosen mengampu matakuliah yang tersedia memberikan 4 warna Hasil tersebut digunakan untuk memetakan dosen dan matakuliah yang diampu dengan ketersediaan kelas untuk memastikan bahwa dosen dengan pilihan matakuliah yang sama harus ditempatkan di kelas yang berbeda. Dalam pemenuhan kebutuhan kelas, satu dosen dapat mengampu beberapa mata kuliah dan satu mata kuliah dapat diampu oleh beberapa dosen. Hasil penerapan Algoritma Welch-Powell terhadap kesediaan waktu mengajardosen memberikan 29 warna Hasil tersebut digunakan untuk memetakan waktu perkuliahan untuk memastikan bahwa dosen dengan pilihan waktu yang sama harus ditempatkan di kelas yang berbeda.
\end{abstract}

Kata Kunci: Vertex, Colouring, Welch-Powell's Algorithm

\section{PENDAHULUAN}

Penjadwalan adalah bentuk pengambilan keputusan yang memainkan peran penting dalam banyak disiplin ilmu. Penjadwalan yang dimaksudkan dalam tulisan ini dimaksudkan sebagai pengaturan waktu (timetabling). Petrovic \& Burke menyatakan pengatur waktu sebagai masalah penempatan sumber daya tertentu, tunduk pada kendala, ke dalam sejumlah slot waktu terbatas dan tempat-tempat dengan tujuan untuk memenuhi serangkaian tujuan yang dinyatakan sampai batas yang setinggi mungkin.

Di dunia pendidikan, penjadwalan atau pengaturan waktu penting untuk dilakukan dengan tujuan untuk mengoptimalkan organisasi proses belajar mengajar berkaitan dengan pengalokasian sumber daya yang sesuai dengan bidang ilmu dan kesediaan waktu yang dimiliki oleh sumber daya tersebut sebagai 
kendalanya. Pengaturan waktu perkuliahan terdiri dari dua jenis kendala, yakni kendala keras dan kendala lunak. Kendala-kendala keras ditegakkan secara kaku oleh universitas dan karenanya, harus dipenuhi. Solusi yang tidak melanggar batasan keras disebut solusi yang layak (feasible). Kendala keras yang umum adalah sebagai berikut: 1) tidak ada orang yang dapat dialokasikan untuk berada di lebih dari satu tempat pada satu waktu, 2) total sumber daya yang dibutuhkan dalam setiap periode harus dapat dipenuhi oleh sumber daya yang tersedia.

Kendala lunak adalah hal-hal yang diinginkan untuk memuaskan, tetapi hal tersebut tidak terlalu penting. Dalam masalah pengaturan jadwal universitas di dunia nyata, biasanya tidak mungkin untuk memenuhi semua kendala lunak. Kualitas jadwal yang layak dapat dinilai berdasarkan pada seberapa baik kendala lunak dipenuhi. Namun, beberapa masalah sangat rumit sehingga sulit untuk menemukan bahkan solusi yang layak. (Petrovic \& Burke, 2004)

Penjadwalan adalah kegiatan administratif utama di sebagian besar universitas. Tak terkecuali di Universitas pamulang khususnya program studi Matematika, pengaturan waktu perkuliahan selalu dihadapi manajemen setiap semester. Selama ini, meskipun kendala keras selalu terpenuhi, pengaturan waktu perkuliahan dan pembagian mata kuliah masih dilakukan secara manual dan belum sepenuhnya memperhatikan bidang ilmu yang diminati dosen dan kesediaan waktu dosen sehingga belum memperhatikan kendala lunak. Hal tersebut mengakibatkan jadwal yang dihasilkan kurang efektif yang dibuktikan dengan adanya beberapa dosen yang meminta mundur dari tugas yang diberikan dan digantikan dengan dosen lain disebabkan oleh ketidaksesuaian dengan bidang minat dosen maupun kesediaan waktu dosen. Selain itu, adanya perubahan jadwal perkuliahan yang dibuat dan disepakati sendiri oleh dosen dan mahasiswa pada mata kuliah yang diampu di minggu pertama perkuliahan untuk memindahkan waktu perkuliahan sesuai dengan kesediaan waktu yang dimiliki dosen.

Untuk mengatasi permasalahan tersebut, diperlukan langkah atau mekanisme penjadwalan yang tepat dan optimal. Banyak metode maupun algoritma yang dapat digunakan untuk membuat penjadwalan. Penelitian tentang penjadwalan kuliah dengan menggunakan metode constrains programming dan simulated annealing pernah dilakukan oleh (Rochman, 2012); penelitian tentang penyusunan jadwal kuliah di perguruan tinggi dengan metode tabu search (pencarian terlarang) disusun oleh (Sahid, 1998); dan penelitian tentang Penjadwalan Matakuliah Menggunakan Pewarnaan Titik Pada Graf oleh (Syauqi \& Syafwan). Beberapa penelitian yang telah disebutkan tersebut berasal dari berbagai disiplin ilmu seperti riset operasi, artificial intelegence maupun computational intelegence (Rochman, 2012).

Dalam disiplin ilmu komputasi, terdapat pewarnaan graf sebagai salah satu metode penjadwalan. Salah satu algoritma yang dapat digunakan adalah algoritma Welch-Powell."Algoritma Welch Powell merupakan salah satu algoritma pewarnaan graf yang melakukan pewarnaan berdasarkan derajat tertinggi dari simpulsimpulnya atau disebut Largest Degree Ordering (LDO) yaitu dengan melakukan pewarnaan berdasarkan derajat besar ke derajat kecil dan menggunakan satu warna untuk mewarnai simpul pertama dan simpul berikutnya yang tidak berdampingan dengan simpul pertama dan seterusnya" (S, Rosely, \& Mayadewi, 2016)

Dalam tulisan ini, penulis menggunakan algoritma Welch Powell untuk menyusun jadwal pengaturan waktu perkuliahan pada program studi Matematika Universitas Pamulang dengan harapan penjadwalan yang dilakukan 
nantinya akan lebih cepat dan optimal serta lebih memuaskan berbagai pihak yang menggunakan hasil dari penelitian ini.

\section{KAJIAN PUSTAKA Graf}

Berikut ini diberikan pengertian dasar graf yang meliputi pengertian graf itu sendiri, sifat bertetangga, $u-v$ walk, $u-v$ trail, $u-v$ path, lingkaran, jarak serta derajat.

Definisi 2.1. (Chartrand \& Lesniak, 1996) Suatu graf $G$ adalah himpunan tak kosong berhingga simpul $V(G)=\left\{v_{1}, v_{2}, \ldots, v_{n}\right\}$ yang disebut simpul dan himpunan $E(G)=$ $\left\{e_{1}, e_{2}, \ldots, e_{n}\right\}$ merupakan himpunan pasangan tidak berurutan dari anggotaanggota $V(G)$ yang disebut busur.

Setiap graf harus memuat minimal sebuah simpul, tetapi dimungkinkan tidak mempunyai busur. Graf yang himpunan busurnya adalah himpunan kosong dinamakan graf kosong atau null graph. Banyaknya simpul pada suatu graf disebut dengan order, sedangkan banyaknya busur pada suatu graf disebut dengan size.

Definisi 2.2. (Chartrand.G, 1977) Jika $u$ dan $v$ adalah sembarang dua simpul dari graf $G$ yang dihubungkan oleh busur $e$, dinotasikan $e=(u, v)$, maka dikatakan $u$ dan $v$ adalah simpul yang saling bertetangga.

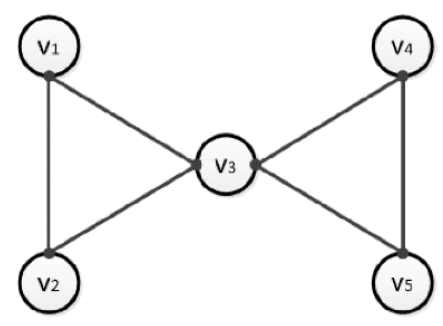

Gambar 1 Graf $G_{1}$

Gambar 1 menunjukkan bahwa simpul $v_{1}$ dan $v_{2}$ saling bertetangga, sedangkan simpul $v_{1}$ dan $v_{4}$ tidak saling bertetangga.Definisi 2.3. (Chartrand \& Lesniak, 1996) Suatu $u-v$ walk dari graf $G$ adalah barisan bergantian antara simpul dan busur yang dimulai dari simpul $u$ dan berakhir di simpul $v$, sehingga $e_{i}=\left(u_{i-1}, u_{i}\right)$ untuk $i=$ $1,2, \ldots, n \quad$ dengan $u=u_{0}, u_{1}, u_{2}, \ldots, u_{n}=v . \quad$ Suatu $u-v$ trail adalah $u-v$ walk dengan tidak mengulang sembarang busur. Suatu $u-v$ path adalah $u-v$ walk yang tidak mengulang sembarang simpul.

Contoh $u-v$ walk dari graf $G$ pada Gambar 1 yaitu $v_{2}, v_{2} v_{1}, v_{1}, v_{1} v_{3}, v_{3}, v_{3} v_{4}$

$v_{4}, v_{4} v_{5}, v_{5}, v_{5} v_{3}, v_{3}, v_{3} v_{1}, v_{1}$. Contoh $u-v \quad$ trail adalah $v_{2}, v_{2} v_{3}, v_{3}, v_{3} v_{5}, v_{5}, v_{5} v_{4}, v_{4}$ $v_{4} v_{3}, v_{3}, v_{3} v_{1}, v_{1}$. Contoh $u-v$ path adalah

$v_{2}, v_{2} v_{1}, v_{1}, v_{1} v_{3}, v_{3}, v_{3} v_{4}, v_{4}, v_{4} v_{5}, v_{5}$.

Definisi 2.4. (Chartrand.G, 1977)

Suatu $u-v$ trail dengan $u=v$, paling sedikit terdiri dari 3 simpul disebut sirkuit. Sirkuit yang tidak mengulang sembarang simpul disebut lingkaran.

Contoh sirkuit pada Gambar 1 yaitu

$v_{2}, v_{2} v_{1}, v_{1}, v_{1} v_{3}, v_{3}, v_{3} v_{4}, v_{4}, v_{4} v_{5}, v_{5}, v_{5} v_{3}$,

$v_{3}, v_{3} v_{2}, v_{2}$. Sedangkan contoh lingkaran dari graf $G$ yaitu $v_{2}, v_{2} v_{1}, v_{1}, v_{1} v_{3}, v_{3}, v_{3} v_{2}, v_{2}$.

Definisi 2.5. (Kusmayadi, 2011) Jarak dari simpul $u$ ke $v$ di $G$ adalah panjang lintasan (path) terpendek dari simpul $u$ ke $v$, dinotasikan dengan $d(u, v)$. Jika tidak ada lintasan yang menghubungkan simpul $u$ dan $v$, maka $d(u, v)=\infty$. Berdasarkan Definisi 2.5, jarak simpul $v_{1}$ ke $v_{5}$ dalam Gambar 1 adalah 2. Definisi 2.6. (Chartrand \& Lesniak, 1996) Derajat dari simpul $v$ di graf $G$ adalah banyaknya sisi di $G$ yang bersisian (incident) dengan $v$, dinotasikan dengan $\operatorname{deg}(v)$.

Simpul yang berderajat genap disebut simpul genap dan simpul yang berderajat ganjil disebut simpul ganjil. Simpul yang berderajat nol disebut isolated vertices dan simpul yang 
berderajat satu disebut simpul ujung. Berikut diberikan contoh graf $G$ yang akan ditentukan derajat simpulnya.

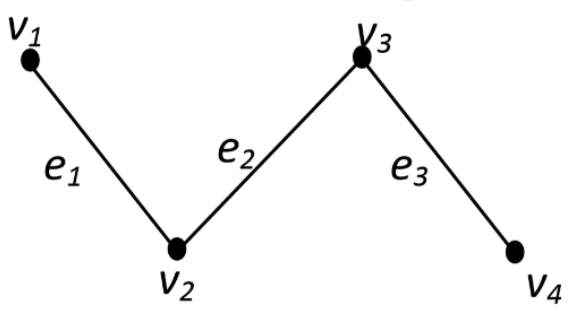

Gambar 2 Graf $G_{2}$

Berdasarkan Gambar 2, diperoleh bahwa $\operatorname{deg}\left(v_{1}\right)=1, \operatorname{deg}\left(v_{2}\right)=$ $2, \operatorname{deg}\left(v_{3}\right)=2, \operatorname{deg}\left(v_{4}\right)=1 . \quad$ Simpul $v_{1}$ dan $v_{4}$ adalah simpul ujung, simpul $v_{2}$ dan $v_{3}$ adalah simpul genap.

\section{Pewarnaan Graf}

Misalkan $G$ adalah graf dan $k$ adalah bilangan bulat positif. Suatu pewarnaan- $k$ untuk graf $G$ adalah cara mewarnai setiap simpul pada graf $G$ dengan $k$ warna sedemikian sehingga setiap dua simpul yang bertetangga tidak mempunyai warna yang sama.

\section{Bilangan Kromatik (Chromatic Number)}

$\begin{array}{ccr}\text { Suatu } & \text { graf } G & \begin{array}{r}\text { dikatakan } \\ \text { bilangan }\end{array} \\ \text { kromatik }\end{array}$
(chromatic number) $k$ atau kromatik- $k$ (k-chromatic) apabila graf $G$ dapat diwarnai dengan $k$-warna, tetapi tidak dengan $(k-1)$-warna. Bilangan Kromatik (chromatic number) dari graf $G$ dinyatakan dengan symbol $(G)$ adalah jumlah warna minimum yang digunakan untuk mewarnai setiap simpul pada graf $G$ sedemikian sehingga setiap dua simpul yang bertetangga tidak mempunyai warna yang sama.

Pada graf kosong $N_{n}$ dapat langsung ditentukan bilangan kromatiknya yaitu $\chi\left(N_{n}\right)=1$, karena setiap simpul tidak bertetangga, maka simpul-simpul di graf kosong dapat diwarnai dengan satu warna saja. Pada graf lengkap $K_{n}, \chi\left(K_{n}\right)=n$, karena setiap simpul saling bertetangga sehingga simpul-simpul dapat diwarnai dengan $n$ warna. Sedangkan pada graf bipartit $G\left(V_{1}, V_{2}\right), \quad \chi(G)=2$, warna pertama untuk simpul-simpul di $V_{1}$ dan warna kedua untuk simpul-simpul di $V_{2}$, karena semua simpul-simpul di $V_{1}$ dan juga $V_{2}$ tidak saling bertetangga.

\section{Algoritma Welch Powell}

Algoritma

Welch-Powell diperlukan dalam pewarnaan simpul suatu graf berdasarkan derajat tertinggi dari semua simpulnya. Algoritma WelchPowell termasuk dalam algoritma Greedy. Algoritma Greedy selain algoritma Welch-Powell adalah algoritma Kruskal's dan algoritma Prim's. Algoritma Welch-Powell merupakan cara yang efisien dalam pewarnaan graf $G$. Langkah-langkah dalam algoritma Welch-Powell sebagai berikut:

1. Urutkan simpul-simpul dari graf $G$ dalam derajat yang menurun. Urutan ini mungkin tidak unik karena beberapa simpul mungkin mempunyai derajat yang sama.

2. Gunakan satu warna untuk mewarnai simpul pertama (yang mempunyai derajat tertinggi) dan simpul-simpul lain (dalam urutan yang berurut) yang tidak bertetangga dengan simpul pertama ini.

3. Ulangi langkah 2 di atas untuk simpul dengan urutan tertinggi yang belum diwarnai.

4. Ulangi penambahan warna-warna sampai semua simpul telah diwarnai.

\section{Pewarnaan Simpul dengan Algoritma Welch-Powell}

Seperti pada penjelasan sebelumnya, misalkan $G$ adalah graf sederhana. Suatu pewarnaan- $k$ graf $G$ merupakan pemakaian sebagian atau semua $k$ warna untuk mewarnai setiap simpul pada graf $G$ sehingga setiap dua simpul yang bertetangga diberi warna 
yang tidak sama. Graf $G$ dikatakan dapat diwarnai dengan $k$-warna ( $k$ Colourable) apabila graf $G$ mempunyai pewarnaan- $k$. Representasi pemberian warna pada simpul dapat menggunakan angka atau warna misalnya merah, hijau, biru, kuning dan lain-lain. Permasalahan utama dalam pewarnaan simpul adalah menentukan jumlah warna yang seminimal mungkin. Jumlah warna yang paling minimal ini dikatakan sebagai bilangan kromatik.

\section{METODE PENELITIAN}

Penelitian ini akan dilaksanakan dalam waktu kurang lebih 6 (enam) bulan sejak ditanda tanganinya kontrak perjanjian penelitian. Sebagai lokasi penelitiannya di Program Studi Matematika Universitas Pamulang. Adapun metode yang dilakukan dalam penelitian ini adalah sebagai berikut:

1. Studi Literatur. Pada tahap ini dilakukan pengumpulan materi yang digunakan menjadi dasar teori untuk memperoleh deskripsi yang lebih jelas mengenai pengaturan waktu (timetabel), Algoritma Welch Powell, pewarnaan Graph.

2. Pengumpulan Data. Data yang digunakan dalam penelitian ini adalah daftar pengampu matakuliah dan kesediaan mengajar dosen Program Studi Matematika Univesitas Pamulang untuk semester Ganjil 2017-2018.

3. Pemanfaatan Algoritma. Dalam memanfaatkan dan mengimplementasikan metode algoritma welch powell terhadap masalah yang dihadapi diperlukan data berupa graf. Data yang ada belum dalam bentuk graf, sehingga perlu dilakukan konversi data. Konversi data yang diperoleh dengan membentuk data tersebut menjadi tabel daftar pengampu matakuliah dan tabel kesediaan mengajar bernilai 0 dan 1 yang mengimplementasikan bahwa pada tabel pengampu matakuliah akan bernilai 1 jika dosen bersedia atau bidang keahliannya merupakan matakuliah tersebut dan akan bernilai 0 jika dosen tidak bersedia atau bidang keahlian dosen bukan matakuliah tersebut.

4. Implementasi Hasil. Selanjutnya, setelah terbentuk tabel pengampu matakuliah, tabel tersebut dikonversi menjadi matriks dengan vertex berupa nama dosen. Hubungan antar vertex tersebut disimbolkan dengan angka 1 jika antara dua dosen mengampu matakuliah yang sama dan angka 0 jika antara dua dosen mengampu matakuliah yang berbeda. Hasil penerapan algoritma Welch-Powell untuk matriks pengampu matakuliah dijadikan dasar pertimbangan untuk menentukan kombinasi dosen dan matakuliah yang diampu. Kombinasi dosen dan matakuliah yang diperoleh akan dipetakan menjadi jadwal penempatan kelas dosen dengan matakuliah yang diampu.

\section{HASIL PENELITIAN}

Penyebaran permohonan mengajar dosen memberikan data pengampu matakuliah yang tersedia pada semester yang diteliti dan data kesediaan waktu mengajar dosen. Dalam data tersebut, terdapat beberapa dosen yang pada semester yang diteliti mengajukan cuti dan tidak mengampu matakuliah apapun, ada pula dosen yang bersedia menyesuaikan jadwal dan ditempatkan dimanapun di semua waktu yang tersedia. Selain itu, kesediaan dan 
keahlian yang diminati dosen terhadap matakuliah juga dipertimbangkan, dengan mempertimbangkan pula kelengkapan kebutuhan matakuliah di semester yang diteliti dengan kesediaan dosen.

\section{Dosen yang menyatakan} kesediaan tanpa menyebutkan jam kesediaan diartikan bersedia di semua waktu pada hari tersebut dengan pembagian waktu perkuliahan pagi dan waktu perkuliahan malam. Dosen yang sedang cuti atau mengampu matakuliah yang tidak tersedia pada semester yang diteliti tidak ditampilkan. Untuk mempermudah pengamatan, data yang telah diperoleh disajikan dalam tabel 1

Tabel 1 menyatakan hubungan antara dosen dengan matakuliah yang diampu. Jika bernilai 1 artinya dosen memberikan kesediaan mengampu matakuliah atau matakuliah tersebut sesuai dengan minat dan keahlian dosen. Sedangkan apabila bernilai 0 artinya dosen tidak bersedia mengampu mata kuliah tersebut atau tidak sesuai dengan minat dan keahlian dosen.

Tabel 1 Daftar Pengampu Matakuliah Semester Ganjil 2017-2018 Program Studi

\begin{tabular}{|c|c|c|c|c|c|c|c|c|c|c|c|c|c|c|c|c|c|c|c|c|c|c|}
\hline Semester & Mata Kuliah & 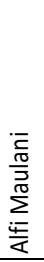 & 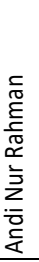 & 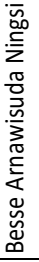 & 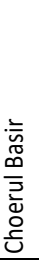 & 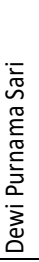 & 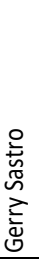 & 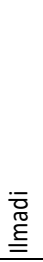 & 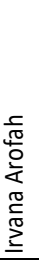 & 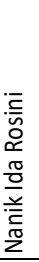 & 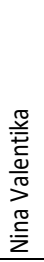 & 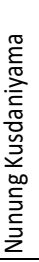 & 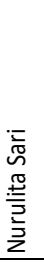 & 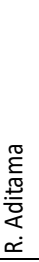 & 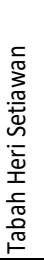 & 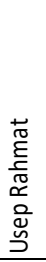 & 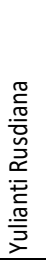 & 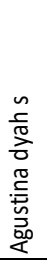 & 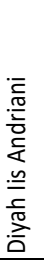 & 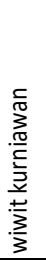 & 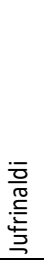 & 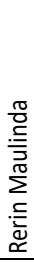 \\
\hline \multirow{9}{*}{1} & Pendidikan Kewarganegaraan & 0 & 0 & 0 & 0 & 0 & 0 & 0 & 0 & 1 & 0 & 0 & 1 & 0 & 0 & 0 & 0 & 0 & 0 & 0 & 0 & 0 \\
\hline & Bahasa Indonesia & 0 & 0 & 0 & 0 & 0 & 0 & 0 & 0 & 0 & 0 & 0 & 0 & 0 & 0 & 0 & 0 & 0 & 0 & 0 & 0 & 1 \\
\hline & Kalkulus I & 1 & 0 & 0 & 0 & 0 & 0 & 1 & 0 & 0 & 1 & 0 & 0 & 0 & 0 & 0 & 0 & 0 & 0 & 0 & 0 & 0 \\
\hline & Kimia Dasar & 0 & 0 & 0 & 0 & 0 & 0 & 1 & 0 & 0 & 0 & 0 & 0 & 0 & 0 & 0 & 0 & 0 & 0 & 0 & 1 & 0 \\
\hline & Bahasa Inggris I & 0 & 0 & 0 & 0 & 0 & 0 & 0 & 0 & 0 & 0 & 0 & 0 & 0 & 0 & 0 & 0 & 0 & 1 & 1 & 0 & 0 \\
\hline & Fisika Dasar I & 0 & 0 & 0 & 0 & 0 & 0 & 1 & 0 & 0 & 0 & 0 & 0 & 0 & 0 & 0 & 0 & 1 & 0 & 0 & 0 & 0 \\
\hline & Praktikum Fisika Dasar I & 0 & 0 & 0 & 0 & 0 & 0 & 1 & 0 & 0 & 0 & 0 & 0 & 0 & 0 & 0 & 0 & 1 & 0 & 0 & 0 & 0 \\
\hline & Pengantar Teknologi Informasi & 0 & 0 & 0 & 0 & 0 & 1 & 0 & 0 & 0 & 0 & 0 & 0 & 0 & 1 & 0 & 0 & 0 & 0 & 0 & 0 & 0 \\
\hline & Trigonometri & 0 & 0 & 0 & 0 & 0 & 0 & 0 & 0 & 0 & 1 & 0 & 0 & 0 & 0 & 0 & 1 & 0 & 0 & 0 & 0 & 0 \\
\hline \multirow{9}{*}{3} & Probabilitas & 0 & 0 & 0 & 0 & 1 & 0 & 1 & 0 & 0 & 0 & 0 & 0 & 0 & 0 & 0 & 0 & 0 & 0 & 0 & 0 & 0 \\
\hline & Teori Bilangan & 0 & 0 & 0 & 0 & 0 & 0 & 0 & 1 & 0 & 0 & 0 & 0 & 0 & 0 & 0 & 1 & 0 & 0 & 0 & 0 & 0 \\
\hline & Matematika Diskrit I & 1 & 1 & 0 & 0 & 0 & 0 & 0 & 0 & 0 & 0 & 0 & 0 & 0 & 0 & 0 & 0 & 0 & 0 & 0 & 0 & 0 \\
\hline & Algoritma \& Pemrograman & 0 & 0 & 0 & 0 & 0 & 1 & 1 & 0 & 0 & 0 & 0 & 0 & 0 & 1 & 0 & 0 & 0 & 0 & 0 & 0 & 0 \\
\hline & Praktikum Algoritma \& Pemrograman & 0 & 0 & 0 & 0 & 0 & 1 & 1 & 0 & 0 & 0 & 0 & 0 & 0 & 1 & 0 & 0 & 0 & 0 & 0 & 0 & 0 \\
\hline & Teknik Lingkungan & 0 & 0 & 0 & 0 & 1 & 0 & 1 & 0 & 0 & 0 & 0 & 0 & 0 & 0 & 0 & 0 & 0 & 0 & 0 & 0 & 0 \\
\hline & Aljabar Linier \& Matriks & 1 & 0 & 0 & 0 & 0 & 0 & 0 & 1 & & 1 & 1 & 0 & 0 & 0 & 0 & 0 & 0 & 0 & 0 & 0 & 0 \\
\hline & Geometri Datar & 0 & 0 & 0 & 1 & 0 & 0 & 0 & 0 & 0 & 0 & 0 & 0 & 1 & 0 & 0 & 0 & 0 & 0 & 0 & 0 & 0 \\
\hline & Bahasa Inggris III & 0 & 0 & 0 & 0 & 0 & 0 & 0 & 0 & 0 & 0 & 0 & 0 & 0 & 0 & 0 & 0 & 0 & 0 & 1 & 0 & 0 \\
\hline \multirow{9}{*}{5} & Program Linier & 0 & 0 & 0 & 0 & 0 & 0 & 1 & 1 & 0 & 0 & 0 & 0 & 0 & 0 & 0 & 0 & 0 & 0 & 0 & 0 & 0 \\
\hline & Geometri Analitik & 0 & 0 & 0 & 1 & 0 & 0 & 0 & 0 & 0 & 0 & 0 & 0 & 1 & 0 & 0 & 0 & 0 & 0 & 0 & 0 & 0 \\
\hline & Statistik Matematika II & 0 & 0 & 0 & 0 & 0 & 0 & 0 & 1 & 0 & 0 & 0 & 0 & 0 & 0 & 0 & 0 & 0 & 0 & 0 & 0 & 0 \\
\hline & Aljabar Abstrak Lanjutan & 0 & 1 & 0 & 0 & 0 & 0 & 0 & 0 & 0 & 0 & 0 & 0 & 0 & 0 & 0 & 1 & 0 & 0 & 0 & 0 & 0 \\
\hline & Praktikum Pemodelan Matematika & 0 & 0 & 1 & 0 & 0 & 0 & 0 & 1 & 0 & 0 & 0 & 0 & 0 & 0 & 1 & 0 & 0 & 0 & 0 & 0 & 0 \\
\hline & Analisis Nyata I & 0 & 0 & 0 & 0 & 0 & 0 & 0 & 0 & 0 & 0 & 0 & 0 & 0 & 0 & 0 & 1 & 0 & 0 & 0 & 0 & 0 \\
\hline & Persamaan Diferensial Parsial & 0 & 1 & 0 & 0 & 0 & 0 & 0 & 0 & 0 & 0 & 0 & 0 & 0 & 1 & 0 & 0 & 0 & 0 & 0 & 0 & 0 \\
\hline & Teori Graf & 0 & 0 & 0 & 1 & 0 & 0 & 0 & 0 & 0 & 0 & 0 & 0 & 1 & 0 & 0 & 0 & 0 & 0 & 0 & 0 & 0 \\
\hline & Pemodelan Matematika & 0 & 0 & 1 & 0 & 0 & 0 & 0 & 1 & 0 & 0 & 0 & 0 & 0 & 0 & 1 & 0 & 0 & 0 & 0 & 0 & 0 \\
\hline & Kewirausahaan & 0 & 0 & 0 & 0 & 1 & 0 & 0 & 0 & 0 & 0 & 0 & 0 & 0 & 0 & 0 & 0 & 0 & 0 & 0 & 0 & 0 \\
\hline & Metode Penelitian & 0 & 0 & 0 & 0 & 0 & 0 & 0 & 0 & 0 & 0 & 0 & 0 & 0 & 1 & 0 & 0 & 0 & 0 & 0 & 0 & 0 \\
\hline & Sistem Informasi Manajemen & 0 & 0 & 0 & 0 & 1 & 0 & 0 & 0 & 0 & 0 & 0 & 0 & 0 & 0 & 0 & 0 & 0 & 0 & 0 & 0 & 0 \\
\hline & Statistik Non Parametrik & 0 & 0 & 0 & 0 & 0 & 0 & 0 & 0 & 0 & 0 & 0 & 0 & 0 & 1 & 0 & 0 & 0 & 0 & 0 & 0 & 0 \\
\hline & Oprasi Riset & 0 & 0 & 0 & 0 & 1 & 0 & 0 & 1 & 0 & 0 & 0 & 0 & 0 & 0 & 0 & 1 & 0 & 0 & 0 & 0 & 0 \\
\hline & Statistik Pengendalian Kualitas & 0 & 0 & 0 & 0 & 0 & 0 & 1 & 0 & 0 & 0 & 0 & 0 & 0 & 0 & 0 & 0 & 0 & 0 & 0 & 0 & 0 \\
\hline & Asuransi & 1 & 0 & 0 & 0 & 0 & 0 & 0 & 0 & 0 & 0 & 0 & 0 & 0 & 0 & 0 & 0 & 0 & 0 & 0 & 0 & 0 \\
\hline & Analisis Kompleks & 0 & 0 & 0 & 0 & 0 & 0 & 0 & 1 & 0 & 0 & 0 & 0 & 0 & 0 & 0 & 0 & 0 & 0 & 0 & 0 & 0 \\
\hline
\end{tabular}


Tahapan selanjutnya dalam proses penelitian adalah merubah tabel pengampu matakuliah ke dalam bentuk matriks graf ketetanggaan dengan vertexnya adalah nama dosen. Hasil konversi Tabel 1 adalah matriks berikut ini

Sebelum pemetaan kombinasi dosen dan matakuliah yang diampu, terlebih dahulu diamati keterhubungan antara dosen dengan matakuliah. Dengan adanya pengamatan ini akan menjadi pertimbangan dalam penempatan kombinasi matakuliah dan penempatan kelas. Hasil penerapan Algoritma WelchPowell terhadap kesediaan atau keahlian dosen mengampu matakuliah yang tersedia memberikan 4 warna dengan pengelompokan titik terhadap warnanya ditampilkan dalam Tabel 2. Hasil tersebut digunakan untuk memetakan dosen dan matakuliah yang diampu dengan ketersediaan kelas untuk memastikan bahwa dosen dengan pilihan matakuliah yang sama harus ditempatkan di kelas yang berbeda.

Tabel 2 Pengelompokan Warna

\begin{tabular}{cccc} 
w1 & w2 & w3 & w4 \\
\hline v7 & v8 & v1 & v10 \\
v16 & v2 & v5 & v6 \\
v11 & v12 & v14 & \\
v3 & v13 & v15 & \\
v4 & v17 & & \\
v9 & v19 & & \\
v18 & v20 & & \\
v21 & & & \\
\hline
\end{tabular}

Hasil pewarnaan diterapkan pada tabel kesediaan dosen mengampu matakuliah disajikan dalam Gambar 3. Berdasarkan pewarnaan tersebut, dapat terlihat bahwa beberapa dosen yang memilih mengampu mata kuliah yang sama mendapatkan perbedaan warna yang artinya jika dosen tersebut mendapatkan mata kuliah yang sama maka tidak dapat ditempatkan dalam kelas yang sama. Jika dosen yang bersangkutan mengajar di kelas yang sama, harus mengampu mata kuliah yang berbeda. Dari tabel tersebut, dapat pula terlihat bahwa pemilihan nama dosen yang mengampu di kelas yang sama dengan mata kuliah berbeda dapat dipertimbangkan dari nama-nama dosen yang memiliki kesamaan warna.

Setelah pengamatan terhadap kesediaan mengampu mata kuliah, dibuatlah kombinasi dosen dan mata kuliah yang diampu. Untuk memenuhi kebutuhan kelas, satu dosen dapat mengampu beberapa mata kuliah dan satu mata kuliah dapat diampu oleh beberapa dosen. Masing-masing hasil kombinasi dosen dan mata kuliah diterapkan ke dalam pembagian kelas sesuai dengan kelas dan matakuliah yang tersedia.

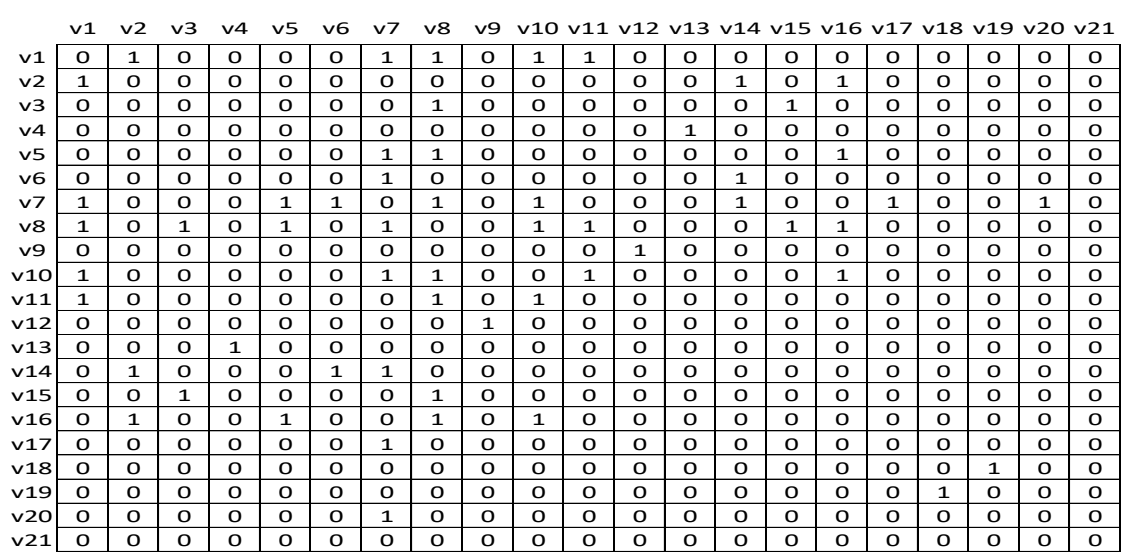




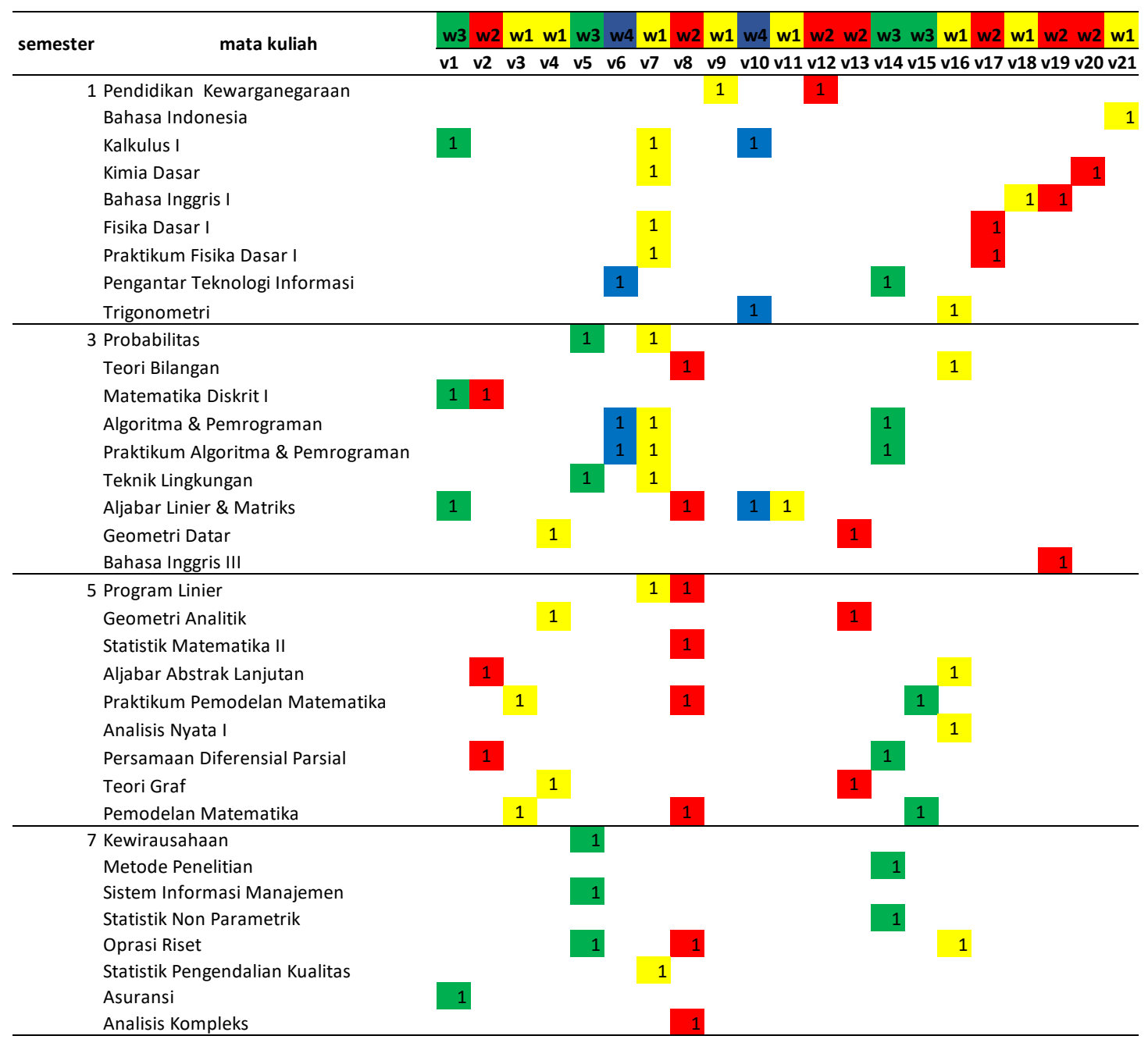

Gambar 3 Pewarnaan data dosen pengampu matakuliah

Proses pengelompokan kelas dilakukan berdasarkan pertimbangan pewarnaan kesediaan mengampu matakuliah. Ketersediaan kelas terbagi berdasarkan dua waktu perkuliahan, yaitu kelas pagi dan kelas malam. Selain pertimbangan kesamaan warna, pertimbangan penting berikutnya adalah kesesuaian dengan bidang keahlian dosen dan kesediaan waktu mengajar kelas pagi dan/atau kelas malam. Dosen yang memiliki keahlian sesuai dengan matakuliah yang dipilih lebih diutamakan.

Hasil kombinasi dosen dan matakuliah yang diampu dari semua kelas dan berdasarkan kesediaan matakuliah yang dipilih dosen di semester ganjil diperoleh sebanyak 67 simpul.

Dari 67 simpul kombinasi dosen dan matakuliah dan berdasarkan kesediaan mengajar yang telah diberikan dosen, terdapat beberapa dosen yang memiliki waktu yang fleskibel atau menyesuaikan keputusan dan dapat ditempatkan di waktu manapun. Untuk menyederhanakan matriks kesediaan, dosen yang memiliki waktu fleksibel tersebut dimunculkan sebagai simpul akan tetapi kesediaan mengajarnya sementara dinolkan yang artinya tidak terkendala waktu manapun. Setelah diterapkan dalam algoritma Welch Powell diperoleh 29 warna yang disajikan dalam Tabel 3 
Tabel 3 Pengelompokan warna berdasarkan simpul kombinasi dosen dan mata kuliah dengan kesediaan waktu mengajar.

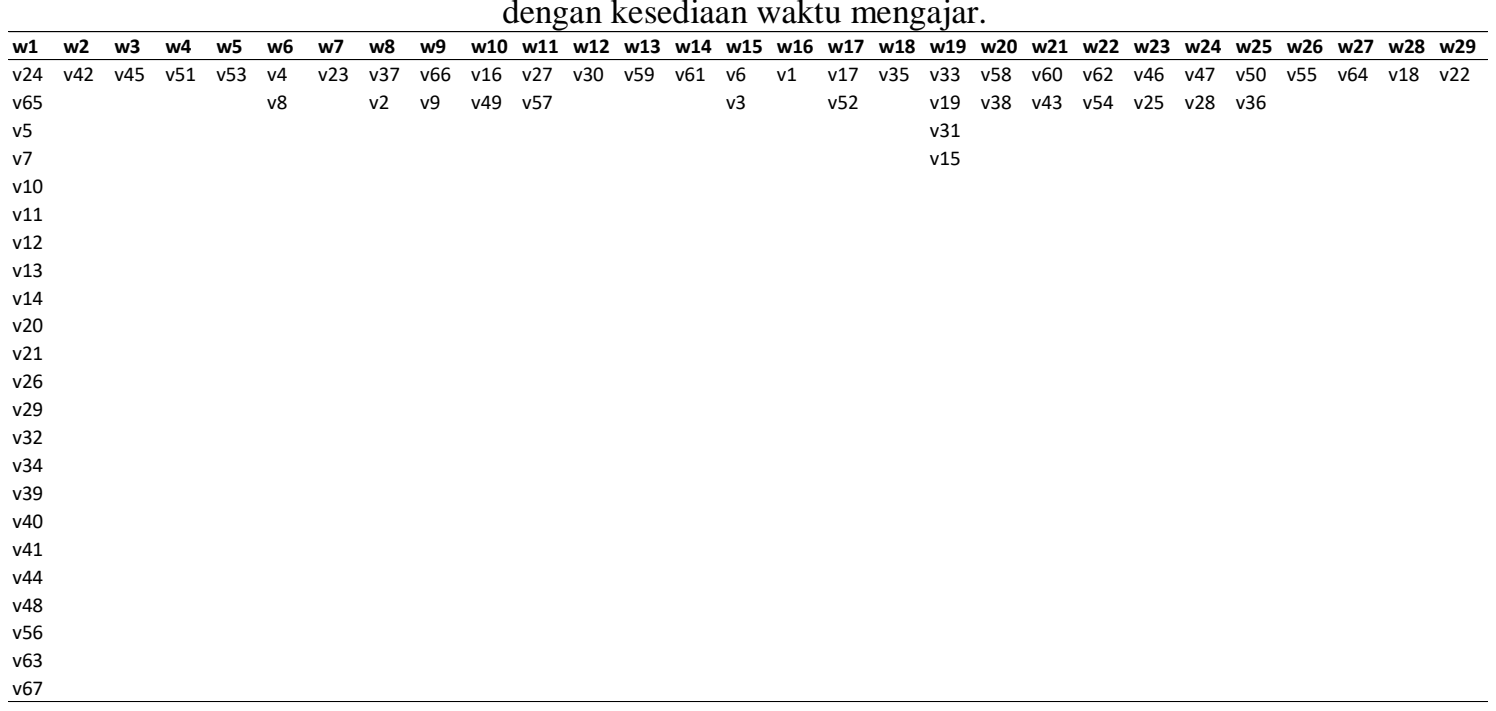

Berdasarkan penyajian warna tersebut, w1 memiliki anggota terbanyak karena dosen dengan kesediaan yang fleksibel atau yang nilainya dinolkan sehingga tidak bertetangga dengan simpul manapun akan masuk ke warna w1 (satu warna dengan simpul yang memiliki derajat tertinggi).

Dengan pertimbangan kesediaan hasil pewarnaan mata kuliah dan pewarnaan waktu pemetaan selanjutnya adalah melakukan pengelompokan semester. Pada semester Ganjil pengelompokan dibagi menjadi 4 yaitu semester 1 , semester 3, semester 5, dan semester 7 . Sebelum pengelompokan kelas, kesediaan dosen yang memiliki waktu fleksibel dikembalikan lagi menjadi bernilai 1. Proses pengelompokan kelas dilakukan berdasarkan pertimbangan pewarnaan kesediaan mengampu matakuliah. Ketersediaan kelas terbagi berdasarkan dua waktu perkuliahan, yaitu kelas pagi dan kelas malam. Pemilihan kelas diawali dengan penentuan pengampu di kelas malam terlebih dahulu. Dikarenakan kendalanya lebih besar mengingat dosen yang memberikan kesediaan hanya kelas malam lebih terbatas jumlahnya. Selain pertimbangan kesamaan warna, pertimbangan penting berikutnya adalah kesesuaian dengan bidang keahlian dosen. Dosen yang memiliki keahlian sesuai dengan matakuliah yang dipilih lebih diutamakan. Hasil pengelompokan kelas disajikan dalam tabel berikut

Tabel 4 Pembagian kelas semester 1

\begin{tabular}{llll}
\hline \multicolumn{1}{c}{ semester 1 } & 01MATP001 & 01MATP002 & 01MATM001 \\
\hline Pendidikan Kewarganegaraan & v9 & v9 & v12 \\
\hline Bahasa Indonesia & v21 & v21 & v21 \\
\hline Kalkulus I & v1 & v10 & v10 \\
\hline Kimia Dasar & v20 & v20 & v20 \\
\hline Bahasa Inggris I & v18 & v18 & v19 \\
\hline Fisika Dasar I & v17 & v17 & v17 \\
\hline Praktikum Fisika Dasar I & v17 & v17 & v17 \\
\hline Pengantar Teknologi Informasi & v14 & v14 & v6 \\
\hline Trigonometri & v16 & v16 & v10 \\
\hline
\end{tabular}


Tabel 5 Pembagian kelas semester 3

\begin{tabular}{llll}
\hline \multicolumn{1}{c}{ semester 3 } & 03MATP001 & 03MATP002 & 03MATM001 \\
\hline Probabilitas & v5 & v5 & v7 \\
\hline Teori Bilangan & v16 & v16 & v8 \\
\hline Matematika Diskrit I & v2 & v1 & v2 \\
\hline Algoritma \& Pemrograman & v7 & v7 & v6 \\
\hline Praktikum Algoritma \& Pemrograman & v7 & v7 & v6 \\
\hline Teknik Lingkungan & v5 & v5 & v7 \\
\hline Aljabar Linier \& Matriks & $\mathrm{v} 1$ & $\mathrm{v} 10$ & $\mathrm{v} 11$ \\
\hline Geometri Datar & $\mathrm{v} 4$ & $\mathrm{v} 4$ & $\mathrm{v} 13$ \\
\hline Bahasa Inggris III & $\mathrm{v} 19$ & $\mathrm{v} 19$ & $\mathrm{v} 19$ \\
\hline
\end{tabular}

Tabel 6 Pembagian kelas semester 5

\begin{tabular}{llll}
\hline \multicolumn{1}{c}{ semester 5 } & 05MATP001 & 05MATP002 & 05MATM001 \\
\hline Program Linier & v7 & v7 & v8 \\
\hline Geometri Analitik & v4 & v4 & v13 \\
\hline Statistik Matematika II & v8 & v8 & v8 \\
\hline Aljabar Abstrak Lanjutan & v16 & v16 & v2 \\
\hline Praktikum Pemodelan Matematika & v3 & v3 & v15 \\
\hline Analisis Nyata I & v16 & v16 & \\
\hline Persamaan Diferensial Parsial & v2 & v2 \\
\hline Teori Graf & v4 & v4 & v13 \\
\hline Pemodelan Matematika & v3 & v3 & v15 \\
\hline
\end{tabular}

Tabel 7 Pembagian kelas semester 7

\begin{tabular}{|c|c|c|c|}
\hline semester 7 & 07МАТР001 & 07МАТМ001 & 07МАТМ002 \\
\hline Kewirausahaan & v5 & & \\
\hline Metode Penelitian & v14 & v14 & v14 \\
\hline Sistem Informasi Manajemen & v5 & & \\
\hline Statistik Non Parametrik & v14 & v14 & v14 \\
\hline Operasi Riset & v16 & v8 & v8 \\
\hline Statistik Pengendalian Kualitas & v7 & v7 & v7 \\
\hline Asuransi & v1 & v1 & v1 \\
\hline Analisis Kompleks & v8 & v8 & v8 \\
\hline
\end{tabular}

\section{PEMBAHASAN}

Berdasarkan pembagian kelas tersebut, tidak semua kendala terpenuhi, terdapat beberapa simpul yang mendapat kelas atau tatap muka melebihi beban kerja dosen dan terdapat pula beberapa kelas yang belum mendapatkan simpul disebabkan tidak ada kesediaan dosen yang memenuhi. Oleh karena itu, sebelum ke tahap selanjutnya perlu dilakukan modifikasi penataan kelas dengan melanggar beberapa kendala. Adapun beberapa kendala tersebut adalah

1. Menempatkan dosen sesuai matakuliah yang diampu dengan memaksakan kesediaan waktu yang diberikan; atau 
2. Menempatkan dosen sesuai kesediaan waktu dengan memaksakan matakuliah dengan asumsi masih sesuai dengan kemampuan akademik dosen yang bersangkutan.

Karena kesediaan waktu termasuk kendala keras, maka kemungkinan kedua yang lebih memungkinkan untuk dilanggar. Berdasarkan pembagian kelas dan pewarnaan kesediaan waktu mengajar, dapat disusun jadwal perkuliahan.

\section{SIMPULAN}

Algoritma Welch-Powell dapat diterapkan dalam penjadwalan mata kuliah semester ganjil 2017-2018 di Program Studi Matematika, Fakultas Matematika dan Ilmu Pengetahuan Alam, Universitas Pamulang dengan membentuk matriks penyesuaian antara kesediaan mengampu matakuliah dosen simpulnya adalah dosen yang bersangkutan. Berdasarkan matriks kesediaan mengampu matakuliah di semester ganjil, dapat dihasilkan 4 warna yakni warna w1 beranggotakan v7, v16, v11, v3, v4, v9, v18, v21; warna w2 beranggotakan v8, v2, v12, v13, v17, v19, v20; warna w3 beranggotakan v1, v5, v14, v15; dan warna w4 beranggotakan v10, v6. Dari keempat warna tersebut, penerapannya jika simpul berada dalam satu warna, artinya simpul tersebut tidak bertetangga sehingga dapat ditempatkan di kelas yang sama, sedangkan jika berbeda warna, artinya simpul tersebut bertetangga sehingga harus ditempatkan di kelas yang berbeda dan hanya dapat ditempatkan di kelas yang sama jika mengampu matakuliah yang berbeda.

Berdasarkan matriks kesediaan waktumengajar di semester ganjil, dari 67 simpul dapat dihasilkan 29 warna. Dengan w1 beranggotakan simpul dengan derajat tertinggi dan simpul dosen dengan waktu yang fleksibel yang diatur tidak bertetangga dengan siapapun.

\section{DAFTAR PUSTAKA}

Chartrand, G., \& Lesniak, L. (1996). Graphs and Digraphs (Third ed.). Boca Raton. London. New York. Washington, D.C: Chapman and Hall/CRC.

Chartrand.G. (1977). Introductory of Graph Theory. New York: Western Michigan University. Dover Publications,inc.

Kusmayadi, T. A. (2011). Graf dan Digraf Eksentrik. UNS Press.

Petrovic, S., \& Burke, E. (2004). University Timetabling. Dalam J.

Y.-T. Leung, Handbook of Schedulling, Algorithms, models, and Performance Analysis. Boca Raton London New York Washington, D.C.: CRC Press Company.

Rochman, A. (2012). Penjadwalan Kuliah dengan menggunakan Metode Constrains Programming dan Simulated Annealing. Seminar nasional Aplikasi Teknologi Informasi 2012. Yogyakarta.

S, D. H., Rosely, E., \& Mayadewi, R. P. (2016). Penerapan Algoritma Welch Powell Dengan Pewarnaan Graph Pada Penjadwalan Mata Pelajaran Sma. Seminar Nasional Sistem Informasi Indonesia.

Sahid. (1998). Penyusunan Jadwal Kuliah di Perguruan Tinggi dengan Metode Tabu Search (Pencarian Terlarang). Jurnal Iptek dan Humaniora, 27-45.

Syauqi, Z. A., \& Syafwan, M. (t.thn.). Penjadwalan Matakuliah Menggunakan Pewarnaan Titik Pada Graf. Jurnal Matematika UNAND. 